\title{
RES Efficiency Indicators for Portugal, Spain and Germany
}

\author{
F. Martins and C. Felgueiras
}

\begin{abstract}
Nowadays one of the most important strategies in the European Union and in the World to solve energy problems is RES energy production. Many investments and financial supports are being done and implemented in many countries. However it is very relevant to have parameters and merit figures that help to evaluate the investments done and solutions implemented and that can be useful in the definition of future pathways and energy systems. In this work are calculated efficiency indicators to RES technologies for three EU's Member States, namely Portugal, Spain and Germany that are internationally recognized to have a significant role in RES implementation and integration.
\end{abstract}

Index Terms - Energy, RES, efficiency indicators.

\section{INTRODUCTION}

Many countries around the world including European Union (EU) Members are trying to solve energy problems using RES (Renewable energy sources) [1]-[3]. Increasing energy demand and instability of markets and prices are challenges that nowadays pose serious risks to the development of countries affecting their competitiveness, economies and sustainable development. These factors along with the uneven distribution of fossil fuels, the risk of supply interruptions and high external energy dependency contributed to new policies especially in EU that have established a new policy based on the use of RES, increasing efficiency and reduction of greenhouse gas emissions which originated the known EU 20-20-20 strategy. This shift on the EU's energy policy was also brought new laws, namely the Directive 2009/28/EC on renewable energy that set a target of $20 \%$ renewable energy in gross final energy consumption by 2020. In order to reach this target all Member States have national targets which requires national action plans that promote the implementation of renewable energy sources. To achieve these targets several factors are critical, namely the technological development of RES, the cost of RES technologies, available support instruments and current and planning funding among others. In EU Members there are several instruments used to subsidise renewable energy: feed-in tariffs, quota obligations, fiscal incentives, public financing, etc. there are aimed to promote RES implementation [1], [4]. In Portugal is being used feed-in tariffs while in Spain it is possible to choose between receiving a regulated feed-in tariff or the market price and a participation prize [5]. At a global level it is worth mention

Manuscript received April 28, 2014; revised July 2, 2014.

F. Martins is with the REQUIMTE/ISEP, Portugal (e-mail: ffm@isep.ipp.pt).

C. Felgueiras is with the LABORIS/ISEP, Portugal (e-mail: mcf@isep.ipp.pt) that the year 2012 was declared the International Year of Sustainable Energy for All by United Nations General Assembly. The initiative Sustainable Energy for ALL has three interconnected objectives to 2030, namely to provide universal access to modern energy services, double the global rate of improvement in energy efficiency and also doubling the share of renewable energy in global energy mix. This shows that RES implementation is a worldwide strategy although some regions/countries are more committed to it than others. Although renewable energy is spreading around the world in many countries it represents a small share in the energy mix and globally production from RES is still a small portion.

Traditional energy production systems, based on fossil fuels, can be considered very controllable. On the other hand production of energy from RES and their integration in power systems are intrinsically non controllable (wind, solar, some hydro). This poses important technical problems in what concerns energy systems management. While the share of energy from RES is small this problem is manageable as experience has already shown in many countries. However when the share increases control limitations become visible and solutions must be thought. The way RES integration is done, namely if the RES production have priority over the production from other sources is a very important factor. When this happens management can become even more difficult due not only to unpredictability of most RES but also to their higher fluctuations. This imposes serious constrains on the electrical system/grid since it has its own limitations [6]. Incidents have already been registered in Portugal and Spain [7]. In order to prevent blackouts it is necessary to have back-up plants with increasing capacity and reliable (mainly based on fossil fuels). In Portugal thermal power plants working with gas are basically working on conditions of start-stop just to face wind energy production fluctuations [7]. The main problem is to keep the balance between energy demand and production which is can be a very complicated task when considering unpredictable and by consequence non controllable energy sources such as most RES. Electricity produced by wind power plants in Portugal is already being used in hydropower plants for water storage but this strategy is not enough to solve the problem if the target is to keep increasing the share of RES. Since one of the main objectives of energy systems is provide energy without ruptures or power failures even when dealing with energy sources that are intermittent (wind, PV, etc.) new solutions can involve new aspects such as smart grids and/or super grids connecting several countries within a region among other aspects .

Many efforts around the world are being made to implement and integrate RES in energy systems by strategic planning and financial supports but these investments should be validated to define future investments and pathways to 
obtain sustainable energy systems. Different scenarios for future are now being considered and studied however what the future power system will look like is not fully clear [8], [9]. However several authors agree that use of RES will favour present and future generations due to their economic, environmental and social advantages [10], [11].

\section{RES EFFICIENCY INDICATOR}

Usually to characterized the implementation of RES technologies in a given country are used the installed power capacity and the energy production for RES [1]. These parameters are very important to analyze and evaluate the present situation of RES in the several countries, regions or World. However it is also important to relate installed capacity for a RES technology and the energy produced with that power capacity to better understand the integration of RES in current power systems and/or the efficiency obtained with current installed power capacity, defining an efficiency indicator, $E I_{R E S}$ :

$$
E I_{R E S}=\frac{E P}{I P C}
$$

where $E P$ is an energy production from a given RES technology and IPC is the correspondent installed power capacity for that RES technology. The $E I_{R E S}$ relates the production of energy obtained with the installed capacity. It can be useful to understand how current investments and systems are being used. It can also be used to define measures to improved current systems before decide, for example, to do new investments in a RES technology that has not achieved its full potential at current situation. These indicators can also be very useful to decide what new investments should be made in a country or region.

\section{ANALYSIS OF RES EFFICIENCY INDICATORS FOR SELECTED COUNTRIES}

In this work are evaluated and analyzed the efficiency indicators for the several RES, Wind, Solar, Hydro, Biomass and waste, geothermal and global RES for three EU's Member States, namely Portugal, Spain and Germany. Portugal and Spain were selected because their systems present high share of RES in electricity production, even when comparing them with other countries outside the EU or Europe. Germany was selected because it is one country that has been making investments in RES being in the top five in the world considering total capacity as of end-2012, being the first one when considering Solar PV [1]. Only China, United States, Brazil and Canada present higher total capacity. Considering the countries mentioned Brazil and Canada present the highest share of production from RES, respectively $86.5 \%$ and $64.5 \%$, but the production is mainly from hydro energy, with percentages above $92 \%$ (for the year 2011). This type of RES can be more controllable than wind or solar. They are followed by Portugal, Spain and Germany, respectively with $47.6 \%, 35.3 \%, 22.1 \%$ (2011) and finally China with $19.7 \%$ for the year of 2010 and United States with $12.8 \%$ (2011). In China the production is also mainly from hydro energy, with percentages above $92 \%$ (for the year
2010). But Portugal, Spain and Germany presented a different scenario with a more complementary mix especially Germany as can be seen in Table I.

TABLE I: SHARE OF ENERGY FROM THE DIFFERENT RES

\begin{tabular}{ccccccc}
\multicolumn{6}{c}{ TABLE I: SHARE OF ENERGY FROM THE DIFFERENT RES } \\
\hline Country & Year & $\begin{array}{c}\text { Share } \\
\text { wind }\end{array}$ & $\begin{array}{c}\text { Share } \\
\text { Solar,Tide, } \\
\text { wave }\end{array}$ & $\begin{array}{c}\text { Share } \\
\text { Hydro }\end{array}$ & $\begin{array}{c}\text { Share } \\
\text { Biomass } \\
\text { and Waste }\end{array}$ & $\begin{array}{c}\text { Share } \\
\text { Geothermal }\end{array}$ \\
\hline Portugal & 2005 & 19.8 & 0.0 & 57.2 & 22.1 & 0.8 \\
Portugal & 2011 & 36.7 & 1.1 & 48.5 & 12.9 & 0.8 \\
Spain & 2005 & 50.4 & 0.1 & 42.1 & 7.4 & 0.0 \\
Spain & 2011 & 48.7 & 10.5 & 34.8 & 6.0 & 0.0 \\
Germany & 2005 & 42.2 & 2.0 & 30.1 & 25.7 & 0.0 \\
Germany & 2011 & 36.5 & 14.9 & 14.3 & 34.2 & 0.0
\end{tabular}

Tables II-Table IV present the production of energy from RES for Portugal, Spain and Germany in the period 2005 2011 and it is possible to conclude that Germany is the country with the highest production (data from Direcção Geral de Energia e Geologia, PT and International Energy Statistics).

TABLE II: PRODUCTION OF ELECTRICITY FROM RES FOR PORTUGAL

\begin{tabular}{ccccccc}
\hline Year & $\begin{array}{c}\text { Wind } \\
\text { Million } \\
\text { MWh }\end{array}$ & $\begin{array}{c}\text { Solar } \\
\text { Million } \\
\text { MWh }\end{array}$ & $\begin{array}{c}\text { Hydro } \\
\text { Million } \\
\text { MWh }\end{array}$ & $\begin{array}{c}\text { Biomass } \\
\text { and Waste } \\
\text { Million } \\
\text { MWh }\end{array}$ & $\begin{array}{c}\text { Geothermal } \\
\text { Million } \\
\text { MWh }\end{array}$ & $\begin{array}{c}\text { Total } \\
\text { Million } \\
\text { MWh }\end{array}$ \\
\hline 2005 & 1.77 & 0.00 & 5.12 & 1.98 & 0.07 & 8.94 \\
2006 & 2.93 & 0.01 & 11.47 & 2.00 & 0.09 & 16.48 \\
2007 & 4.04 & 0.02 & 10.45 & 2.14 & 0.20 & 16.85 \\
2008 & 5.76 & 0.04 & 7.30 & 2.13 & 0.19 & 15.42 \\
2009 & 7.58 & 0.16 & 9.01 & 2.38 & 0.18 & 19.31 \\
2010 & 9.18 & 0.21 & 16.55 & 2.90 & 0.20 & 29.04 \\
2011 & 9.16 & 0.28 & 12.11 & 3.22 & 0.21 & 24.99 \\
\hline
\end{tabular}

TABLE III: PRODUCTION OF ELECTRICITY FROM RES FOR SPAIN

\begin{tabular}{ccccccc}
\hline Year & $\begin{array}{c}\text { Wind } \\
\text { Million } \\
\text { MWh }\end{array}$ & $\begin{array}{c}\text { Solar,Tide, } \\
\text { wave } \\
\text { Million } \\
\text { MWh }\end{array}$ & $\begin{array}{c}\text { Hydro } \\
\text { Million } \\
\text { MWh }\end{array}$ & $\begin{array}{c}\text { Biomass } \\
\text { and Waste } \\
\text { Million } \\
\text { MWh }\end{array}$ & $\begin{array}{c}\text { Geothermal } \\
\text { Million } \\
\text { MWh }\end{array}$ & $\begin{array}{c}\text { Total } \\
\text { Million } \\
\text { MWh }\end{array}$ \\
\hline 2005 & 21.18 & 0.04 & 17.69 & 3.10 & 0.00 & 42.01 \\
2006 & 23.30 & 0.12 & 25.63 & 3.38 & 0.00 & 52.42 \\
2007 & 27.57 & 0.51 & 26.96 & 3.64 & 0.00 & 58.67 \\
2008 & 32.95 & 2.58 & 23.30 & 4.04 & 0.00 & 62.86 \\
2009 & 38.12 & 6.06 & 26.07 & 4.25 & 0.00 & 74.50 \\
2010 & 44.17 & 7.11 & 41.86 & 4.68 & 0.00 & 97.80 \\
2011 & 42.37 & 9.12 & 30.29 & 5.22 & 0.00 & 87.00 \\
\hline
\end{tabular}

TABLE IV: PRODUCTION OF ELECTRICITY FROM RES FOR GERMANY

\begin{tabular}{ccccccc}
\hline Year & $\begin{array}{c}\text { Wind } \\
\text { Million } \\
\text { MWh }\end{array}$ & $\begin{array}{c}\text { Solar,Tide, } \\
\text { wave } \\
\text { Million } \\
\text { MWh }\end{array}$ & $\begin{array}{c}\text { Hydro } \\
\text { Million } \\
\text { MWh }\end{array}$ & $\begin{array}{c}\text { Biomass } \\
\text { and Waste } \\
\text { Million } \\
\text { MWh }\end{array}$ & $\begin{array}{c}\text { Geothermal } \\
\text { Million } \\
\text { MWh }\end{array}$ & $\begin{array}{c}\text { Total } \\
\text { Million } \\
\text { MWh }\end{array}$ \\
\hline 2005 & 27.23 & 1.28 & 19.39 & 16.59 & 0.00 & 64.49 \\
2006 & 30.71 & 2.22 & 19.73 & 21.34 & 0.00 & 74.00 \\
2007 & 39.71 & 3.08 & 20.69 & 29.07 & 0.00 & 92.56 \\
2008 & 40.57 & 4.42 & 20.73 & 29.22 & 0.02 & 94.96 \\
2009 & 38.64 & 6.58 & 18.47 & 35.56 & 0.02 & 99.27 \\
2010 & 37.79 & 11.68 & 20.22 & 39.87 & 0.03 & 109.59 \\
2011 & 46.50 & 19.00 & 18.19 & 43.57 & 0.02 & 127.28 \\
\hline
\end{tabular}


Production of energy from RES such as wind, solar and hydro can be largely affected by geographic conditions and climate and weather conditions. Efficiency indicators for Portugal and Spain due to their near geographic position should be similar and can expectably differ from Germany since it is situated in central Europe. Tables V to Table VIII present the efficiency indicators for each RES for the countries selected in the period 2005-2011. Table IX presents the efficiency indicator for RES global.

TABLE V: EFFICIENCY INDICATORS FOR WIND FOR SELECTED COUNTRIES

\begin{tabular}{cccc}
\hline \multicolumn{4}{c}{ Efficiency Indicator (Wind) MWh/kW } \\
\hline Year & PT & ES & DE \\
\hline 2005 & 1.67 & 2.14 & 1.48 \\
2006 & 1.72 & 1.99 & 1.49 \\
2007 & 1.64 & 1.86 & 1.79 \\
2008 & 1.88 & 1.98 & 1.70 \\
2009 & 2.13 & 2.00 & 1.50 \\
2010 & 2.35 & 2.13 & 1.39 \\
2011 & 2.09 & 1.96 & 1.60 \\
\hline
\end{tabular}

For wind it is possible to verify that Portugal and Spain present similar values to the efficiency indicators especially after 2008. The deviations registered for Germany are higher and the trend is to obtain smaller values.

Portugal has a small value for production from solar so any variations tend to have a great effect in the indicators but even so it is possible to verify that Portugal and Spain present closer values to the efficiency indicators. Germany presents smaller values when comparing with Portugal and Spain which an expectable outcome due to climate characteristics. This trend is more evident in the last years when implementation of solar is more consolidated especially when considering Spain and Germany (Table III and Table IV).

For hydro it is possible to verify that Portugal and Spain present similar values to the efficiency indicators and that Germany presents consistently much higher values to the indicators.

For biomass and waste it is possible to verify that Portugal and Spain present usually closer values to the efficiency indicators and that Germany presents consistently higher values to the indicators.

Production from geothermal sources it is not significant for the countries considered so the efficiency indicators were not presented although the values for efficiency indicators obtained were very high which indicates that geothermal source may have some potential where its implementation is possible.

TABLE VI: EFFICIENCY INDICATORS FOR SOLAR FOR SELECTED COUNTRIES

\begin{tabular}{cccc}
\hline \multicolumn{4}{c}{ Efficiency Indicator(Solar) $\mathrm{MWh} / \mathrm{kW}$} \\
\hline Year & PT & ES & DE \\
\hline 2005 & 1.00 & 0.68 & 0.85 \\
2006 & 1.47 & 0.66 & 0.78 \\
2007 & 1.66 & 0.68 & 0.81 \\
2008 & 0.61 & 0.75 & 0.83 \\
2009 & 1.45 & 1.61 & 0.67 \\
2010 & 1.60 & 1.55 & 0.67 \\
2011 & 1.63 & 2.11 & 0.76 \\
\hline
\end{tabular}

TABLE VII: EFFICIENCY INDICATORS FOR HYDRO FOR SELECTED COUNTRIES

\begin{tabular}{cccc}
\hline \multicolumn{4}{c}{ Efficiency Indicator $($ Hydro) $\mathrm{MWh} / \mathrm{kW}$} \\
\hline Year & PT & ES & DE \\
\hline 2005 & 1.06 & 1.37 & 4.68 \\
2006 & 2.37 & 1.98 & 4.77 \\
2007 & 2.15 & 2.07 & 5.89 \\
2008 & 1.50 & 1.78 & 5.91 \\
2009 & 1.84 & 1.98 & 4.65 \\
2010 & 3.38 & 3.17 & 4.77 \\
2011 & 2.27 & 2.28 & 3.80 \\
\hline
\end{tabular}

TABLE VIII: EFFICIENCY INDICATORS FOR BIOMASS AND WASTE FOR SELECTED COUNTRIES

\begin{tabular}{cccc}
\hline & \multicolumn{3}{c}{ Efficiency Indicator (Biomass and waste)MWh/kW } \\
\hline Year & PT & ES & DE \\
\hline 2005 & 4.15 & 4.47 & 4.73 \\
2006 & 4.10 & 4.58 & 5.17 \\
2007 & 4.35 & 4.85 & 6.06 \\
2008 & 4.88 & 5.67 & 5.78 \\
2009 & 4.75 & 4.90 & 5.81 \\
2010 & 4.07 & 4.89 & 5.88 \\
2011 & 4.53 & 5.18 & 6.13 \\
\hline
\end{tabular}

TABLE IX: EFFICIENCY INDICATORS FOR TOTAL RES FOR SELECTED COUNTRIES

\begin{tabular}{cccc}
\hline \multicolumn{4}{c}{ Efficiency Indicator (Total RES) MWh/kW } \\
\hline Year & PT & ES & DE \\
\hline 2005 & 1.40 & 1.78 & 2.34 \\
2006 & 2.33 & 2.05 & 2.33 \\
2007 & 2.15 & 2.00 & 2.69 \\
2008 & 1.83 & 1.86 & 2.51 \\
2009 & 2.12 & 2.02 & 2.18 \\
2010 & 3.00 & 2.48 & 1.97 \\
2011 & 2.35 & 2.16 & 1.93 \\
\hline
\end{tabular}

\section{CONCLUSIONS}

This analysis calculated the efficiency indicators for the different RES in three different EU's countries where two of them, Portugal and Spain, have some climate and weather characteristics that can be considered similar and another country, Germany, with different characteristics. It is possible to conclude that efficiency indicators calculated present values that are consistent with those climate and weather differences. It is of great importance that information be gathered by member states to confirm if the differences in the efficiency indicators are only a consequence of different climate and weather conditions or if other parameters such as energy system/grids also influence these results. Within a country it is possible to see differences from one year to another and the collection of information mentioned previously is also important to detect the problems/constraints in the energy systems

These indicators together with climate and weather conditions as well as information on existing technical problems can be useful to understand how current systems 
are performing. It can be used to define measures to improved current systems helping to reach optimum values concerning climate and weather conditions, before decide, for example, to do new investments in a RES technology that has not achieved its full potential at current situation. These indicators can help in the evaluation of investments done and help to define future pathways. These indicators can also be very useful to decide what new investments should be made in a country using local characteristics to its full potential and enhancing complementary (within countries or regions) of energy systems in order to increase share of RES and sustainable energy systems.

For Portugal and Spain the Sta Logaia to Baixas line that will allow the electricity interconnection between Spain and France will increase the security of the Portuguese and Spanish electrical systems reducing the possibility of blackouts. It will allow for the integration of renewable energies produced not only in Spain (wind, hydro, and solar) but potentially of Portugal which will created a space for the growth of RES in Iberian Peninsula. This project is expected to be operational by December 2014. This project will potentially influence the values of efficiency indicators and future work will go further in these analyses and in the use of the presented indicators.

\section{REFERENCES}

[1] REN21, Renewables 2013 Global Status Report, 2013.

[2] A. O. Pereira, R. C. Costa, C. V. Costa, J. M. Marreco, and E. L. LaRovere, "Perspectives for the expansion of new renewable energy sources in Brazil," Renewable and Sustainable Energy Reviews, vol. 23, pp. 49-59, 2013.

[3] G. L. Zou, "The long-term relationships among China's energy consumption sources and adjustments to its renewable energy policy," Energy Policy, vol. 47, pp. 456-467, 2012.

[4] ECOFYS, Financing Renewable Energy in the European Energy Market, 2011.

[5] F. G. Montoya, M. J. Aguilera, and F. Manzano-Agugliaro, "Renewable energy production in Spain: A review," Renewable and Sustainable Energy Reviews, vol. 33, pp. 509-531, 2014.
[6] G. M. Shafiullah, A. M. T. Oo, A. B. M. S. Ali, and P. Wolfs, "Potential challenges of integrating large-scale wind energy into the power grid - A review," Renewable and Sustainable Energy Reviews, vol. 20, pp. 306-321, 2013.

[7] C. P. Nunes and P. S. Nunes, "Contributo para os cenários de avaliação económico-tecnológica relativos à eventual instalação de novas potências eólicas em Portugal," Notas Explicativas Complementares Energia e o Futuro, pp. 46-53, 2013.

[8] S. Spiecker and C. Weber, "The future of the European electricity system and the impact of fluctuating renewable energy-A scenario analysis," Energy Policy, vol. 65, pp. 185-197, 2014.

[9] EREC, Rethinking 2050, A 100\% Renewable Energy Vision for the European Union, 2010.

[10] E. K. Stigka, J. A. Paravantis, and G. K. Mihalakakou, "Social acceptance of renewable energy sources: A review of contingent valuation applications," Renewable and Sustainable Energy Reviews, vol. 32, pp. 100-106, 2014.

[11] N. L. Panwar, S. C. Kaushik, and S. Kothari, "Role of renewable energy sources in environmental protection: A review," Renewable and Sustainable Energy Reviews, vol. 15, pp. 1513-1524, 2011.

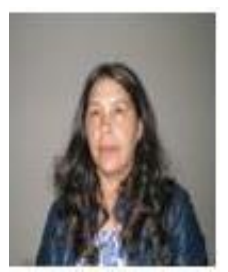

Florinda Martins obtained a $\mathrm{PhD}$ degree in chemical and biological engineering, a master degree in environmental engineering and a degree in chemical engineering from the Faculty of Engineering, University of Porto, Porto, Portugal, in 2007, 1998 and 1989 , respectively. She has also worked in industry and nowadays is an adjunct professor at Instituto Superior de Engenharia do Porto (ISEP), School of Engineering, Polytechnic Institute of Porto (IPP), Porto, Portugal. Her research interests include sustainability, environment, energy and optimization.

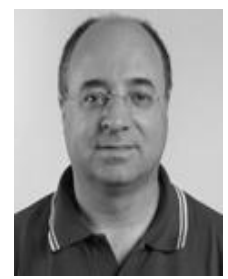

Manuel Carlos Felgueiras received the B.S. and $\mathrm{Ph} . \mathrm{D}$. degrees in electrical and computer engineering from the Faculty of Engineering, University of Porto, Porto, Portugal, in 1987 and 2008, respectively. He started his activity in 1994 as an assistant professor and later on as an adjunct professor and researcher with the Department of Electrical Engineering, School of Engineering, Polytechnic Institute of Porto (IPP), Porto, Portugal.

His research interests include design for debug and test of mixed-signals, remote experimentation in e-learning and renewable energy sources. 

Wind Energy 
